\title{
PENGARUH MODEL PEMBELAJARAN EXPERIENTIAL LEARNING TERHADAP MOTIVASI BELAJAR SISWA PADA MATERI EKOSISTEM
}

\author{
Widiya Septian Dewi ${ }^{1) a}$, Anita Restu Puji Raharjeng ${ }^{2)}$ \\ 1) Prodi Pendidikan Biologi, Fak. Ilmu Tarbiyah dan Keguruan, UIN Raden Fatah Palembang \\ Jl. Prof. K. H. Zainal Abidin Fikri No. 1 A KM 3.5, Palembang 30126, Indonesia. \\ ${ }^{2)}$ Prodi Pendidikan Biologi, Fak. Ilmu Tarbiyah dan Keguruan, UIN Raden Fatah Palembang \\ Jl. Prof. K. H. Zainal Abidin Fikri No. 1 A KM 3.5, Palembang 30126, Indonesia.
}

${ }^{\text {a)} W i d i y a . s e p t i a n d e w i @ y a h o o . c o . i d ~}$

\begin{abstract}
Students' learning motivation in one of the high schools at Southern OKU is still categorized as low. Based on the results of observation and interview, the cause of low student learning motivation because the teacher does not use the learning model or teaching methods that exist in the teaching and learning process so that students feel bored and saturated. Based on these problems, this study aims to determine whether there is influence of learning model experiential learning on learning motivation. This research was conducted in May 2017. The research method used is experimental method with the research design used is quasi experimental design. Population in this study was all students of class X consisting of 3 classes there are X1, X2, X3 with the number of each class on average 37 students. Class X3 is as experiment class and X1 as control class. Sampling is done by purposive sampling technique. Data collection is using motivation questionnaire as primary data and observation of student learning motivation as secondary data. The results showed that $\mathrm{H}_{0}$ rejected Ha accepted so that the hypothesis states that experiential learning model influence on learning motivation.
\end{abstract}

Keywords: learning model, experiential learning, learning motivation, ecosystem

\section{PENDAHULUAN}

Pendidikan merupakan usaha manusia untuk membina kepribadian sesuai dengan norma di dalam kelompok sosial. Pendidikan berperan penting dalam kehidupan manusia dan seluruh aspek kehidupan memerlukan pendidikan. Perkembangan ilmu dan teknologi berpengaruh terhadap kehidupan masyarakat termasuk bidang pendidikan. Pendidikan merupakan suatu bentuk lingkungan yang bertanggung jawab dalam memberikan asuhan terhadap perkembangan individu, maka dari itu sekolah mempunyai peranan penting dalam membimbing peserta didik untuk mencapai taraf perkembangan melalui pemenuhan tugas-tugas perkembangan secara optimal (Wahyuningsih, 2012). Secara normatif tujuan pendidikan di Indonesia diamanatkan dalam UU No. 20 tahun 2003 tentang Sisdiknas. Undangundang ini menyebutkan bahwa pendidikan bertujuan untuk mengembangkan potensi peserta didik agar menjadi manusia yang beriman dan bertaqwa kepada Tuhan Yang Maha Esa, berakhlak mulia, sehat, berilmu, cakap, kreatif, mandiri dan menjadi warga negara yang demokratis serta bertanggung jawab (Danim, 2013).
Motivasi merupakan konsep yang menjelaskan alasan seseorang berperilaku. Kemampuan yang sama dimiliki oleh dua anak yang memberikan peluang dan kondisi yang sama untuk mencapai tujuan, kinerja dan hasil yang dicapai anak yang termotivasi akan lebih baik dibandingkan dengan anak yang tidak termotivasi (Wahyuningsih, 2012). Menurut Uno (2016) bahwa istilah motivasi berasal dari kata motif yang dapat diartikan sebagai kekuatan yang terdapat dalam diri individu, yang menyebabkan individu tersebut bertindak atau berbuat. Motif tidak dapat diambil secara langsung, tetapi dapat diinterprestasikan dalam tingkah lakunya, berupa rangsangan dorongan atau pembangkit tenaga munculnya suatu tingkah laku tertentu.

Menurut Frada (2012), motivasi pendidikan di Indonesia masih menunjukan kualitas rendah. Salah satu permasalahan mutu pendidikan di Indonesia adalah rendahnya kualitas proses pembelajaran seperti metode mengajar guru yang tidak tepat, kurikulum, manajemen sekolah yang tidak efektif dan kurangnya motivasi siswa dalam belajar. Pembelajaran di kelas yang selama ini berpusat pada guru dan tidak memberikan kesempatan kepada siswa untuk aktif. Guru selalu menggunakan 
metode ceramah tanpa ada variasi lain dalam penyampaian materi pelajaran kepada siswa. Mata pelajaran IPA khususnya Biologi menuntut guru yang profesional untuk menguasai materi secara terpadu. Pemilihan sumber belajar yang tepat akan berimbas pada keberhasilan pengajaran yang dilaksanakan. Menurut Farisma (2014), experiential learning merupakan model pembelajaran yang proses pembelajarannya diarahkan untuk mengaktifkan pembelajaran dalam membangun pengetahuan, keterampilan, dan sikap melalui pengalamannya secara langsung

\section{METODOLOGI PENELITIAN}

Penelitian ini dilaksanakan pada bulan Mei 2017. Jenis penelitian ini adalah eksperimen sedangkan jenis data yang digunakan dalam penelitian ini adalah jenis data kuantitatif. Pendekatan penelitian yang digunakan dalam penelitian ini adalah pendekatan deskriptif kuantitatif, desain penelitian yang digunakan dalam penelitian ini adalah quasi experimental design. Sampel yang diperoleh terdiri dari 2 kelas yaitu kelas eksperimen dan kelas kontrol. Maka sampel yang diambil dua kelas yaitu kelas X1 (kelas kontrol) dan X3 (kelas eksperimen) di salah SMA di OKU Selatan.

Teknik penggumpulan data dengan menggunakan observasi dan angket motivasi belajar siswa. Bentuk observasi yang digunakan adalah observasi partisipasi yaitu observasi yang dilakukan dengan pengamatan langsung pada objek penelitian. Jenis angket yang digunakan dalam penelitian ini adalah angket tertutup skala yang digunakan yaitu skala likert. Setiap siswa diminta untuk menjawab setiap pernyataan dengan pilihan jawaban sangat setuju (SS), setuju (S), tidak setuju (ST), dan sangat tidak sejutu (STS).

\section{HASIL DAN PEMBAHASAN}

Selama proses pembelajaran menggunakan model pembelajaranexperiential learning, dilakukan observasi dari pertemuan pertama sampai pertemuan ketiga. Lembar observasi yang digunakan diperoleh data kegiatan siswa selama proses pembelajaran berlangsung. Hasil pengamatan di kelas eksperimen terdapat 17 siswa yang sangat termotivasi 11 siswa siswa yang termotivasi dan 8 siswa cukup termotivasi dan 0 siswa yang kurang termotivasi. Pada kelas kontrol terdapat 8 siswa yang sangat termotivasi, 9 siswa termotivasi 12 siswa cukup termotivasi dan 8 siswa kurang termotivasi

Angket yang digunakan terdiri dari 20 butir pernyataan dan mempunyai alternatif jawaban diberikan skor sesuai dengan alternatif jawaban masing-masing untuk menganalisis data angket tersebut maka setiap butir pernyataan mempunyai empat alternatif. Hasil rekapitulasi angket motivasi belajar siswa pada kelas eksperimen dapat dilihat pada Tabel 1.

Tabel 1. Hasil Rekapitulasi Angket Motivasi Belajar Siswa Pada Kelas Eksperimen

\begin{tabular}{cccc}
\hline \hline No & Kategori & Pretest & Postest \\
\hline 1. & Tinggi & $17 \%$ & $33 \%$ \\
& & & \\
2. & Sedang & $55 \%$ & $59 \%$ \\
3. & Rendah & $28 \%$ & $8 \%$ \\
& Jumlah & $100 \%$ & $100 \%$ \\
\hline \hline
\end{tabular}

Persentase setiap kategori motivasi belajar siswa kelas eksperimen dapat dilihat pada Gambar 1.

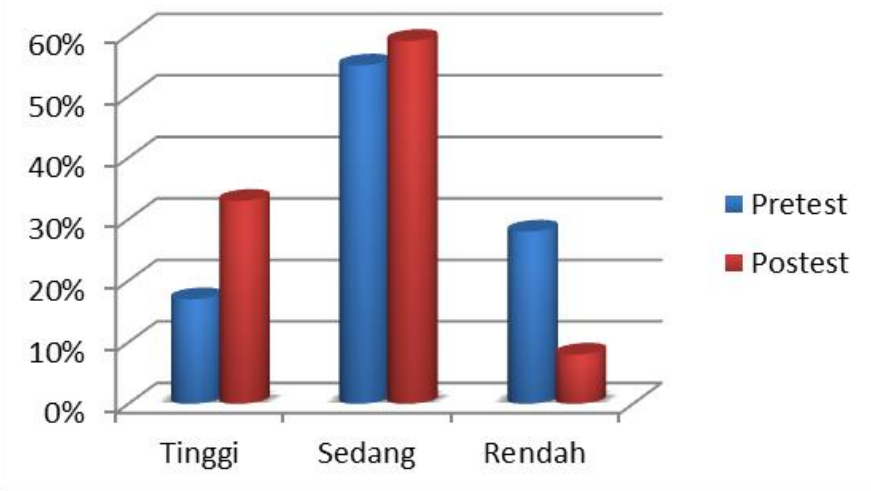

\section{Gambar 1. Persentase Setiap Kategori Motivasi Belajar Siswa Kelas Eksperimen}

Persentase nilai pretest dan postest angket motivasi belajar siswa kelas eksperimen menunjukkan bahwa motivasi belajar siswa kategori tinggi meningkat. Hasil pretest siswa yang 
termasuk kategori tinggi terdapat $17 \%$ setelah dilaksanakan proses pembelajaran dengan menggunakan model pembelajaran experiential learning meningkat menjadi $33 \%$. Pada motivasi belajar siswa kategori sedang juga meningkat, sebelum dilaksanakan proses pembelajaran dengan menggunakan model experiential learning terdapat $55 \%$ siswa yang termasuk kategori sedang, setelah dilaksanakan proses pembelajaran dengan menggunakan model experiential learning meningkat menjadi 59\% siswa yang termasuk kategori sedang. Jumlah siswa yang termasuk kategori motivasi rendah menurun, sebelum dilaksanakan proses pembelajaran dengan menggunakan model pembelajaran experiential learning terdapat $28 \%$ yang termasuk kategori rendah kemudian menurun menjadi $8 \%$ siswa yang termasuk kategori rendah. Hasil rekapitulasi angket motivasi belajar siswa pada kelas control dapat dilihat pada Tabel 2 .

Tabel 2. Hasil Rekapitulasi Angket Motivasi Belajar Siswa Pada Kelas Control

\begin{tabular}{cccc}
\hline \hline No & Kategori & Pretest & Postest \\
\hline \hline 1. & Tinggi & $24 \%$ & $24 \%$ \\
2. & Sedang & $62 \%$ & $62 \%$ \\
3. & Rendah & $14 \%$ & $14 \%$ \\
& Jumlah & $100 \%$ & $100 \%$ \\
\hline \hline
\end{tabular}

Persentase setiap kategori motivasi belajar siswa kelas kontrol dapat dilihat pada Gambar 2 .

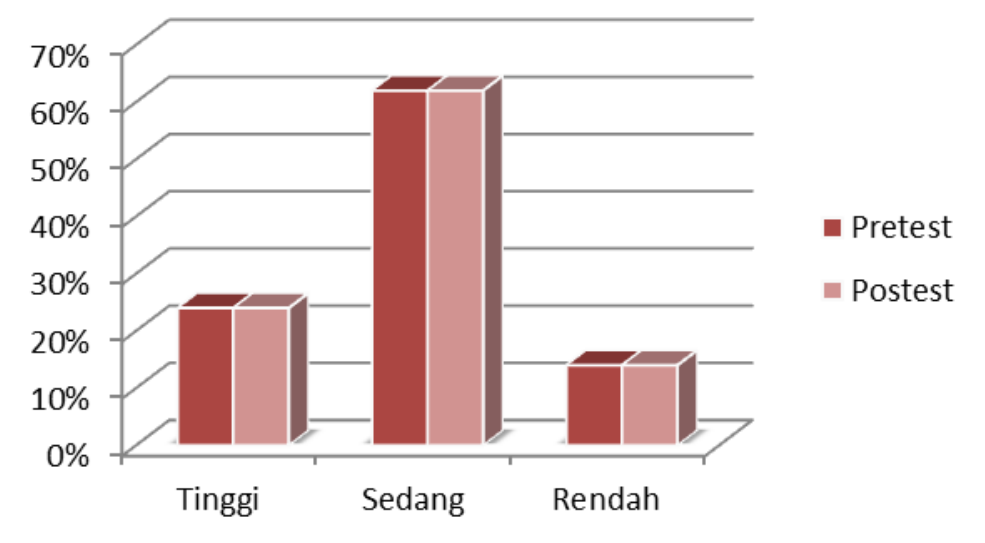

Gambar 2. Persentase Setiap Kategori Motivasi Belajar Siswa Kelas Kontrol

Persentase nilai pretest dan postest angket motivasi belajar siswa kelas kontrol menunjukkan bahwa motivasi belajar siswa kategori tinggi tidak terjadi peningkatan ataupun penururnan. pretest siswa yang termasuk kategori tinggi terdapat $24 \%$ setelah dilaksanakan proses pembelajaran dengan menggunakan metode ceramah persentase skor yang didapat yaitu 24. Pada motivasi belajar siswa kategori sedang juga tidak terjadi peningkatan maupun penurunan, sebelum dilaksanakan proses pembelajaran dengan menggunakan metode ceramah terdapat $64 \%$ siswa yang termasuk kategori sedang, setelah dilaksanakan proses pembelajaran dengan menggunakan metode ceramah meningkat menjadi $64 \%$ siswa yang termasuk kategori sedang. Jumlah siswa yang termasuk kategori motivasi rendah juga tidak mengalami perubahan, sebelum dilaksanakan proses pembelajaran dengan menggunakan metode ceramah terdapat $14 \%$ yang termasuk kategori rendah dan hasil posstetst tetap persentase siswa yang termasuk kategori rendah yaitu $14 \%$.

\section{KESIMPULAN}

Berdasarkan hasil penelitian dan pembahasan pada bab sebelumnya maka dapat disimpulkan bahwa terdapat pengaruh model pembelajaran experiential learning terhadap motivasi belajar siswa teri ekosistem matapelajaran Biologi kelas X SMA di OKU Selatan. Hal ini dapat diketahui dari hasil penelitian nilai skor kategori motivasi belajar siswa pada kelas eksperimen yang menggunakan model pembelajaran experiential learning lebih tinggi daripada kelas kontrol dengan menggunakan metode konvensional (ceramah). Selain itu, hasil analisis nilai angket menunjukkan bahwa $\mathrm{H}_{0}$ ditolak dan $\mathrm{H}_{\mathrm{a}}$ diterima. Oleh sebab itu, hipotesis menyatakan bahwa model pembelajaran experiential learning berpengaruh terhadap motivasi belajar. 


\section{UCAPAN TERIMA KASIH}

Penulis mengucapkan terima kasih kepada semua pihak yang telah memberikan dukungan untuk penelitian ini.

\section{DAFTAR PUSTAKA}

[1] Danim, S. 2013. Pengantar Kependidikan. Bandung: Alfabeta.

[2] Farisma, S. D. 2014. Keefektifan Penggunaan Metode Pembelajaran Berbasis Pengalaman (Experiential Learning) Dalam Meningkatkan Keterampilan Menulis Karangan Argumentasi SiswaKelas X Man Yogyakarta III. http://web.iaincirebon.ac.id/ebook/repository/1 27360078_Euis\%2014ok.pdf. Diaksespada hari Selasa, 25 Oktober 2016, pukul 13.30 WIB.

[3] Frada, S. 2012. Implementas Model Cooperative Learning Teknik Make A Match Untuk Meningkatkan Motivasi Belajar I PS Pada Kelas VIII A SM N 1Wedi, Klaten. htt
p://eprints.uny.ac.id/8787/2/BAB\%201\%20\%2 008416241030.pdf. Diakses pada 18 Januari 2017. Pukul 10.30 WIB.

[4] Murtono, 2013. Pendidikan Sains dalam Alqura $n$. Tersedia di Website: http://digilib.uin suka.ac.id/8698/1/m urtono\%20pendidikan\%20sains\%20dalam\%alquran.pdf. Diakses pada hari Senin, 07 Agustus 2017. Pukul 15.45 WIB.

[5] Rustaman, N. 2012 .Strategi Belajar Mengajar Biologi. Malang: UM Press.

[6] Uno. H. B. 2016. Teori Motivasi dan Pengukurannya Analisis di Bidang Pendidikan. Jakarta: Bumi Aksara.

[7] Wahyuningsih, P. 2012. Faktor-Faktor yang Menyebabkan Rendahnya Motivasi Belajar Siswa dalam Mata Pelajaran Sosiologi Kelas XI Madrasah Aliyah Iman Kota Magelang. http://lib.unnes.ac.id/3067/1/1659.pdf. Diakses pada hari Senin, 03 Oktober 2016 pada Pukul 13.30 WIB. 